\title{
Influence of replacement of fish meal with the earthworm Eisenia fetida on growth performance, feed utilization and blood parameters of Nile tilapia (Oreochromis niloticus)
}

\begin{abstract}
A total of 450 of Oreochromis niloticus fingerlings with initial average weight of $4.10 \pm 0.02 \mathrm{~g}$ were obtained by the Fish Hatchery of the General Authority for Fisheries Development, Aswan governorate, to evaluate the effect of replacement of fish meal with earthworm meal (EWM), on growth performance, survival and blood parameters of Nile tilapia. The stocking density was 30 fingerlings per tank and each diet was tested in triplicate. Fish were manually fed with experimental diets at the rate of $5 \%$, twice/day for 60 days. Once every ten days, the total number of survivors in each tank was counted and fish biomass determined. Crude protein content of Nile tilapia juveniles increased significantly $(\mathrm{P}<0.01)$ for juveniles maintained at the control, 75, 100\% EWM. While average lipid content less for Juveniles fed at $0 \%$ EWM. The Juveniles maintained at 75, 50, and 100\% EWM were have significantly $(\mathrm{P}<0.01)$ higher SGR, PPV, PER, ER and the best food conversion ratio FCR (wait/gain) than the other Juveniles. There were no significant differences $(P<0.01)$ in mean values of creatinine, triglyceride, lipase, glucose, albumin and globulin among all the diets, while cholesterol and amylase varied significantly.
\end{abstract}

Keywords: blood parameters, Eisenia fetida, creatinine, triglyceride, food conversion ratio, tilapia
Volume 9 Issue 2 - 2020

\author{
Ragaa A Ahmed,' Hemdan Sayed Eissa, ${ }^{2}$ \\ Manal Esam Shafi, ${ }^{3}$ Mohamed YM Aly, ${ }^{4}$ \\ Omayma M Abd Al-Kareem ${ }^{5}$ \\ 'Department of Aquaculture, Aswan University, Egypt \\ ${ }^{2}$ Mariculture research centre, Egypt \\ ${ }^{3}$ Zoology department of biological sciences, King Abdulaziz \\ University, Saudi Arabia \\ ${ }^{4}$ Pollution Laboratory, National Institute of Oceanography and \\ Fisheries (NIOF), Egypt \\ ${ }^{5}$ Department of Fish Health and Diseases, Aswan University, \\ Egypt
}

Correspondence: Mohamed YM Aly, Pollution Laboratory, National Institute of Oceanography and Fisheries (NIOF), Egypt, Emailmyahya120@yahoo.com

Received: February 27, 2020 | Published: April 06, 2020

\section{Introduction}

In the last three decades, global fish production has doubled, with an average annual growth rate of $8 \%$. Freshwater fish account for the largest share of global fish production, exceeding $56.4 \%$, which means 33.7 million tonnes of total fish production. ${ }^{1}$ The global population is doubling rapidly, especially in recent decades, and $76 \%$ of this increase is concentrated in Africa and Asia, mostly in developing countries, where, the population increase is expected to reach 12 billion people in the year 2100, Population increase means increased consumption and thus the depletion of environmental resources available for agricultural development. ${ }^{2}$ It is predictable that the large population increase is the main reason for this increase in the fish production sector, in addition to the growing interest in fish production in fresh water, where it is characterized by ease and cheapness compared to fish production of marine water. Goddard ${ }^{3}$ believes that fish meal, which is the main protein source in fish feed composition, is the best source of protein due to its growth rate, palatable taste, fish attractiveness, amino acid content balance, vitamins. However, according to Sogbesan ${ }^{4}$ higher fish production costs and higher prices of high-quality fishmeal with increasing demand have led fish production specialists to seek alternatives to fishmeal to ensure continuity and expansion of global fish production. Also, high-quality fishmeal will not be available to supply endless global fish production as it is a constrained source of fisheries. ${ }^{5}$

In previous research, fishmeal was replaced by earthworm meal in a semi-intensive aquaculture system. ${ }^{6}$ The fingerlings of Heteroclarias spp. were fed after replacing fishmeal in feed with earthworm Eudrilus eugeniae ${ }^{7}$ of domesticated earthworms, Eisenia fetida is known to be the most active species in the production of vermicompost. ${ }^{8}$ Vermicompost is a natural environmentally friendly technology that can convert organic waste into a good and beneficial organic product, a fertilizer containing many humus and antibacterial enzymes, known as vermicompost. ${ }^{9}$

E.fetidaisa promising product, and a good basis for animal nutrition, containing 60 to $70 \%$ of raw protein on the basis of dry matter and many of the ingredients that feed raw materials lack,,$^{10}$ for example, essential amino acids such as alanine, threonine, lysine and arginine. In addition, it is rich in fatty acids, such as linolenic acid (C18:3), linoleic acid (C18:2) and octadecanoic acid (C18:0). ${ }^{11}$ Also Gunya et al. ${ }^{12}$ have found large amounts of other nutrients such as zinc, manganese, copper and phosphorus iron.

The aim of the current study is to evaluate the effect of replacement of fish meal with E. fetida on growth performance, survival and blood parameters of Nile tilapia (Oreochromis niloticus).

\section{Materials and methods}

\section{Experimental fish}

A total of 450 of $O$. niloticus fingerlings with initial average weight of $4.1 \pm 0.02 \mathrm{~g}$ were obtained by the Fish Hatchery of the General Authority for Fisheries Development, the Lake Development Authority. Aswan governorate. The fish were acclimated for a period of one week in the laboratory. The stocking density was 30 fingerlings per tank and each diet was tested in triplicate. Fish were manually fed 
with experimental diets at the rate of $5 \%$, twice per day for a period of 60 days.

Water temperature was recorded by mercury thermometer, dissolved oxygen by metteler Toledo, model 128.s/No1242. pH was measured every three days by $\mathrm{pH}$ meter (Extech $\mathrm{pH} /$ temp pen model $\mathrm{pH}$ 60). Total alkalinity, Ammonia and free carbon dioxide were determined according to Standard Methods. ${ }^{13}$

Once every ten days, the total number of survivors in each tank was counted and fish biomass determined. The proximate composition of E. fetida and formulated diets was evaluated. Moisture content was determined by differential weighing of dried and fresh samples. Crude protein was determined by the macro-kjeldahl method. Ash content was measured by weighing after drying and ashing at $500^{\circ} \mathrm{C}$ in a muffle furnace. Ether extract or crude fat was estimated by ether extraction method. Crude fiber was found out by acid digestion of residues from the ether extraction and loss in weight on ignition.

\section{Collection of earthworms}

Five plastic buckets (Plates) were used as culturing containers for earthworms. Cow manure was used as sources of nutrients for earthworms with dried rice straws and tree leaves as bedding materials.
Three $\mathrm{kg}$ of soil from earthworms' natural environment was collected and mixed with $20 \%$ cow manure. The culture was set with bedding materials at the bottom of each Plastic buckets, followed with equal number of adult earthworms in the substrates. Thereafter bedding materials placed on the top of mixtures to improve their housing as advised by Sherman S. ${ }^{14}$ The worm cultures were placed under shade and covered with the mosquito nets. Each culture substrate was moisturized by one half liter of water once a week. Earthworms was washed thoroughly with water to ensure any impurities stuck to them were eliminated. Then it was grinded and dried at $30^{\circ} \mathrm{C}$ for $24 \mathrm{~h}$ using an oven and sieved to obtain earthworm meal in homogenized form.

\section{Experimental diets}

Five iso-nitrogenous ( $25 \%$ crude protein) experimental diets were formulated and prepared in the fish nutrition lab in faculty of fish and fisheries technology- Aswan University. Experimental diets were prepared to incorporate earthworm meal at four graded levels namely $0.25 \%\left(\mathrm{~T}_{25}\right), 50 \%\left(\mathrm{~T}_{50}\right), 75 \%\left(\mathrm{~T}_{75}\right)$ and $100 \%\left(\mathrm{~T}_{100}\right)$. Diet without earthworm served as control $\left(\mathrm{T}_{0}\right)$. The composition chemical analyses of the experimental diets (on dry matter (DM) basis) are presented in Table 1.

Table I The composition and chemical analysis (\% on dry matter basis) of the experimental diets

\begin{tabular}{|c|c|c|c|c|c|}
\hline \multirow[b]{2}{*}{ Ingredients } & \multicolumn{5}{|c|}{ Experimental diets composition/kg } \\
\hline & $\mathrm{T}_{0}$ & $\mathrm{~T}_{25}$ & $\mathrm{~T}_{50}$ & $\mathrm{~T}_{75}$ & $T_{100}$ \\
\hline Fish meal & 98.0 & 73.5 & 49.0 & 24.5 & 0.0 \\
\hline Earthworm meal & 0.00 & 24.50 & 49.00 & 73.50 & 98.00 \\
\hline Soybean meal & 140.0 & 140.0 & 140.0 & 140.0 & 140.0 \\
\hline Yellow corn & 170.0 & 170.0 & 170.0 & 170.0 & 170.0 \\
\hline Gluten & 200.0 & 200.0 & 200.0 & 200.0 & 200.0 \\
\hline Rice bran & 180.0 & 180.0 & 180.0 & 180.0 & 180.0 \\
\hline Wheat flour & 110.0 & 110.0 & 110.0 & 110.0 & 110.0 \\
\hline Premix ${ }^{\prime}$ & 8 & 8 & 8 & 8 & 8 \\
\hline Fish oil & 30 & 30 & 30 & 30 & 30 \\
\hline Sunflower oil & 30 & 30 & 30 & 30 & 30 \\
\hline Ascorbic acid & 4 & 4 & 4 & 4 & 4 \\
\hline \multirow[t]{2}{*}{ Total } & 1000 & 1000 & 1000 & 1000 & 1000 \\
\hline & \multicolumn{5}{|c|}{ Chemical composition \% } \\
\hline Dry mater & 89.65 & 89.4 & 89.61 & 89.52 & 89.86 \\
\hline Moisture & 10.35 & 10.6 & 10.39 & 10.48 & 10.14 \\
\hline Crude protein $(\mathrm{N} \times 6.25)$ & 30.08 & 29.96 & 29.84 & 29.71 & 29.59 \\
\hline Crude fat & 14.24 & 14.02 & 13.09 & 12.21 & 11.52 \\
\hline Crude fiber & 1.56 & 1.51 & 1.2 & 1.35 & 1.24 \\
\hline Ash & 6.12 & 6.72 & 7.13 & 7.64 & 8.28 \\
\hline Carbohydrate (NFE) ${ }^{2}$ & 37.65 & 37.19 & 38.35 & 38.61 & 39.23 \\
\hline Gross energy kcal/ $100 \mathrm{~g}^{3}$ & 459.779 & 456.9 & 456.2 & 452.4 & 451 \\
\hline
\end{tabular}

'Vit./min. Premix (mgkg-1); 'Premix Composition: Each I kg contains Vit A (400000 i.u.),Vit D3 (I00000 i.u.), Vit E (230mg) Vit K3 (I65mg) Vit BI (300mg),Vit B2 ( $80 \mathrm{mg})$, Vit B6 (200mg), Vit BI2 (I mg), Vit C (650mg), Niacin (I000mg), Methionine(3000 mg), Choline chloride (I0000mg), Folic acid (I00mg), Biotin (2mg), Pantothenic acid $(220 \mathrm{mg})$, Magnesium sulphate (I000mg), Copper sulphate (I000mg), Iron sulphate (330mg), Zinc sulphate (600 mg), Cobalt sulphate (I00mg), Calcium carbonate up to $(1000 \mathrm{mg})$.

${ }^{2} \mathrm{NFE}=100-[\%$ Ash $+\%$ lipid $+\%$ protein $+\%$ Fiber $]$

${ }^{3}$ Gross energy (GE) was calculated as $5.64,9.44$ and 4.1 I kcal/I00g for protein, lipid and NFE, respectively (NRC, I993). 
The feed were calculated using Pearson's square method, with these as the major ingredients;
a. Fish meal-crude protein $(65 \%)$
b. Earthworm meal-crude protein $(60 \%)$
c. Soybean meal-crude protein $(45 \%)=0.68 \mathrm{~kg}$
d. Yellow corn-crude protein $(9 \%)$
e. Gluten-crude protein $(60 \%)$
f. Rice bran-crude protein $(13 \%)$
g. Wheat flour-crude protein (14.4\%)

Fish oil was added at $6 \%$ of the total formulated feeds weight for protein-sparing effect on the fish and to improve the feed palatability and binding of the ingredients together. Feed ingredients were fully mixed, homogenized, moistened by the addition of $35 \%$ water and pelleted in a mincing machine. The pellets were dried at $50^{\circ} \mathrm{C}$ for $8 \mathrm{~h}$.

\section{Growth performance and feed utilization efficiency}

At the end of the experiment, fish were harvested, counted, and weighed. The growth performance and feed utilization parameters were calculatedas follows:

A) Specific growth $\operatorname{rate}(\mathrm{SGR})=[(\ln \mathrm{FBW}-\ln \mathrm{IBW}) / \mathrm{t}] \times 100$

where, FBW and IBW = final mean weight and the initial mean weight, respectively; $\mathrm{T}=$ feeding period in days.

B) Survival rate $\%=[(\mathrm{NF} / \mathrm{Ni}) \times 100]$

where, $\mathrm{NF}=$ final total number of fish;

$\mathrm{Ni}=$ initial total number of fish.

C) Feed conversion ratio $(\mathrm{FCR})=$ Total feed intake $(\mathrm{g}) /$ Total weight gain $(\mathrm{g})$

D) Protein efficiency ratio $(\mathrm{PER})=$ Total weight gain $(\mathrm{g}) /$ Protein intake

E) Body weight gain $(B W G)=W t-W i$
F) Protein efficiency ratio (PER)=wet weight gain $(\mathrm{g}) /$ total protein intake $(g)$

\section{Blood sampling and biochemical analyses}

At the end of experiment which was conducted over 8 weeks, five fish were removed from the tank and used as replicates. Blood samples were taken from the caudal vein of each fish as described by Congleton and La Voie. ${ }^{15}$ Each sample was centrifuged at 3000rpm for 10 minutes to obtain serum for biochemical studies. The serum was kept at $-20^{\circ} \mathrm{C}$ until analysis of creatinine, cholesterol, triglycerides, amylase, lipase, glucose, albumin and globulin. colorimetric determinations of biochemical parameters were performed using a spectrophotometer. We measured the following biochemical assays; quantitative estimation of creatinine $(\mathrm{mg} / \mathrm{dl})$ was estimated according to Henry. ${ }^{16}$ Blood serum glucose was measured by Glucose Oxidase method. Serum cholesterol $(\mathrm{mg} / \mathrm{dl})$ was estimated by Enzymatic Colorimetric test. Serum triglycerides by colorimetric method. All these parameters follow procedures according to Chawla. ${ }^{17}$

\section{Statistical analysis}

Data collected on the investigated traits (growth performance, feed utilization, biochemical and blood serum analyses) were analyzed with one-way analysis of variance (ANOVA) using the SPSS version 16 statistical package (SPSS Company Inc., Chicago, IL. USA) to evaluate the differences between the tested treatments. The differences within each experimental treatment were assessed using Duncan's multiple range test at the $\mathrm{P}<0.01$ level.

\section{Results and discussion \\ Water quality parameters}

Water temperature were recorded by mercury thermometer, and dissolved oxygen by metteler Toledo, model 128.s/No1242. Where the average range of dissolved oxygen was above $6 \mathrm{mg} / \mathrm{l} . \mathrm{pH}$ was measured every three days by $\mathrm{pH}$ meter (Extech $\mathrm{pH} /$ temp pen model $\mathrm{pH}$ 60). Total alkalinity, Ammonia and free carbon dioxide were determined according to Standard Methods. The mean values of these variables are shown in Table 2.

Table 2 Mean values \pm Se of water quality parameters recorded in different feeding during experimental period

\begin{tabular}{lllll}
\hline Treatment & $\begin{array}{l}\text { Temperature } \\
{ }^{\circ} \mathbf{C}\end{array}$ & $\mathbf{p H}$ & $\begin{array}{l}\text { Dissolved Oxygen } \\
\mathbf{m g / l}\end{array}$ & $\begin{array}{l}\text { Ammonia } \\
\mathbf{m g / l}\end{array}$ \\
\hline $\mathrm{C}$ & $23.4 \pm 0.6$ & $8.1 \pm 0.14$ & $6.8 \pm 0.11$ & $0.014 \pm 0.012$ \\
$\mathrm{~T} 25$ & $24.0 \pm 0.26$ & $8.5 \pm 0.05$ & $7.3 \pm 0.16$ & $0.016 \pm 0.002$ \\
$\mathrm{~T} 50$ & $26.06 \pm 0.22$ & $7.7 \pm 0.13$ & $6.5 \pm 0.30$ & $0.014 \pm 0.003$ \\
$\mathrm{~T} 75$ & $27.6 \pm 0.06$ & $7.8 \pm 0.10$ & $7.5 \pm 0.19$ & $0.063 \pm 0.008$ \\
$\mathrm{~T} 100$ & $27.2 \pm 0.3$ & $7.6 \pm 0.11$ & $7.3 \pm 0.13$ & $0.042 \pm 0.002$ \\
\hline
\end{tabular}

\section{Growth performance and feed utilization}

The effects of replacement of fish meal with E. fetida on growth performance and feed utilization of $O$. niloticus are presented in Table 3. IW, FW and WG at five levels of EWM replacement $\left(\mathrm{T}_{0}, \mathrm{~T}_{25}, \mathrm{~T}_{50}\right.$, $\mathrm{T}_{75}$ and $\left.\mathrm{T}_{100}\right)$ were significantly increased $(\mathrm{P}<0.01)$ with increasing level of EWM from $T_{25}$ to $T_{75}$ replacement after 8 weeks. The survival of the Juveniles maintained at $\mathrm{T}_{100}$ EWM was significantly $(\mathrm{P}<0.01)$ less than Juveniles maintained at the other levels. There were no significant differences for Juveniles maintained at $\mathrm{T}_{0}, \mathrm{~T}_{25}, \mathrm{~T}_{50}$, and $\mathrm{T}_{75}$.

SGRs of the Juveniles maintained at $\mathrm{T}_{75}, \mathrm{~T}_{50}$, and $\mathrm{T}_{100}$ were significantly $(\mathrm{P}<0.01)$ higher than Juveniles maintained at other experimental diets. The least significant SGRs were for Juveniles that maintained at $\mathrm{T}_{0}$ and $\mathrm{T}_{25}$. 
Table 3 Mean values \pm Se of Growth performance and feed utilization of Nile tilapia (O. niloticus) during fed experimental diet for 8 weeks

\begin{tabular}{llllll}
\hline Parameters & $\mathbf{C}$ & $\mathbf{T}_{25}$ & $\mathbf{T}_{50}$ & $\mathbf{T}_{75}$ & $\mathbf{T}_{100}$ \\
\hline Initial BW & 4.1 & 4.16 & 4.07 & 4.13 & 4.13 \\
Survival & $93.33+1.33^{\mathrm{a}}$ & $93.33+1.33^{\mathrm{a}}$ & $93.33+2.67^{\mathrm{a}}$ & $94.67+1.33^{\mathrm{a}}$ & $92+2.31^{\mathrm{b}}$ \\
Final wt & $27.27+0.12^{\mathrm{c}}$ & $28.43+0.09^{\mathrm{bc}}$ & $29.4+0.11^{\mathrm{ab}}$ & $30.50+0.15^{\mathrm{a}}$ & $29.36+0.14^{\mathrm{ab}}$ \\
Gain & $23.17+0.18^{\mathrm{c}}$ & $24.27+0.13^{\mathrm{bc}}$ & $25.33+0.09^{\mathrm{ab}}$ & $26.37+0.18^{\mathrm{a}}$ & $25.23+0.12^{\mathrm{ab}}$ \\
SGR & $3.38+0.03^{\mathrm{c}}$ & $3.43+0.04^{\mathrm{bc}}$ & $3.53+0.01^{\mathrm{a}}$ & $3.57+0.04^{\mathrm{a}}$ & $3.50+0.01^{\mathrm{ab}}$ \\
\hline
\end{tabular}

The best FCR was for those Juveniles fed on diet $\mathrm{T}^{100}$. Juveniles maintained at $\mathrm{T}_{25}, \mathrm{~T}_{50}$, and $\mathrm{T}_{75}$ showed not significant differences in FCR, while the Juveniles maintained at $\mathrm{T}_{0}$ showed the highest FCR.

ER, PPV and PER were affected by different level of FM replacement with EWM. The highest PPV and PER were observed with the larvae fed at $\mathrm{T}_{100}, \mathrm{~T}_{75}$, and $\mathrm{T}_{50}$, respectively but no significant differences. For the control PPV and PER were significantly lower than the other.

It was also observed that ER was significantly higher in $\mathrm{T}_{50}, \mathrm{~T}_{75}$, and $T_{100}$ than $T_{25}$ and $T_{0}$, showing that earthworms contain a high rate of protein, ${ }^{18}$ which has been confirmed to be rich in amino acids necessary for optimal fish growth. Several studies have shown that the earthworm powder content ranges from 48 and $71 \%$ protein. For instance, Serna ${ }^{19}$ showed that E. fetida contained 58 to $71 \%$ protein.

In this study, replacing FM with EWM has led to significant differences between experimental diets on both growth performance and food utilization, as the use of $\mathrm{T}_{75}$ resulted in the highest WG and SGR followed by $\mathrm{T}_{50}$ and then by $\mathrm{T}_{100}$. The fish fed with the control diet achieved a significantly lower WG and SGR. This last result is consistent with Omeru and Solomon. ${ }^{20}$
Whole replacement of FM with EWM in the diet of catfish Clarias gariepinus promote growth performance and survival. It may be sense that this improvement was attributed to containing EWM on eight essential amino acids. ${ }^{21}$

Protein quality generally depends on two important factors, the biological value and the efficiency of use with $E$. fetida contain protein of $84 \%$ biological value and $79 \%$ efficiency in rat growth test and These values are also found in fish and chicken tissues. ${ }^{22}$

From Table 4, it can be concluded that there is a significant increase in the food utilization by increasing the EWM in diets of tilapia juveniles compared to juveniles that were fed a diets $0 \%$ that did not contain EWM. The fish maintained at $\mathrm{T}_{50}, \mathrm{~T}_{75}$, and $\mathrm{T}_{100}$ got the highest values in each of the PPV, PER, ER. While the values were the least significant for the juveniles that maintained at $\mathrm{T}_{0}$.

It seems that the earthworms will soon become a source of nutritional protein in animal feed, in addition to the possibility of using it for humans as well. Earthworm mail protein is easily soluble in digestive enzymes, which is a clear indication of the ease of digestion by fish.

Table 4 Mean values \pm SE of feed utilization of Nile tilapia (O. niloticus) during fed experimental diet for 8 weeks.

\begin{tabular}{llllll}
\hline Parameters & $\mathbf{C}$ & $\mathbf{T}_{25}$ & $\mathbf{T}_{50}$ & $\mathbf{T}_{75}$ & $\mathbf{T}_{100}$ \\
\hline Offered feed & $35.29+0.04^{\mathrm{b}}$ & $35.95+0.16^{\mathrm{b}}$ & $37.01+0.26^{\mathrm{ab}}$ & $38.20+0.16^{\mathrm{a}}$ & $36.22+0.23^{\mathrm{b}}$ \\
FCR & $1.52+0.0 \mathrm{I}^{\mathrm{a}}$ & $1.48+0.0 \mathrm{I}^{\mathrm{ab}}$ & $1.46+0.0 \mathrm{I}^{\mathrm{b}}$ & $1.45+0.0 \mathrm{I}^{\mathrm{b}}$ & $1.43+0.0 \mathrm{I}^{\mathrm{b}}$ \\
PPV & $32.1 \mathrm{I}+0.65^{\mathrm{b}}$ & $33.18+0.06^{\mathrm{ab}}$ & $33.85+0.35^{\mathrm{a}}$ & $33.89+0.13^{\mathrm{a}}$ & $34.49+0.22^{\mathrm{a}}$ \\
PER & $2.19+0.02^{\mathrm{b}}$ & $2.25+0.02^{\mathrm{ab}}$ & $2.28+0.0 \mathrm{I}^{\mathrm{a}}$ & $2.30+0.0 \mathrm{I}^{\mathrm{a}}$ & $2.32+0.0 \mathrm{I}^{\mathrm{a}}$ \\
ER & $15.68+0.54^{\mathrm{c}}$ & $16.04+0.07^{\mathrm{bc}}$ & $17.03+0.2 \mathrm{I}^{\mathrm{ab}}$ & $17.53+0.07^{\mathrm{a}}$ & $17.30+0.08^{\mathrm{a}}$ \\
\hline
\end{tabular}

\section{Biochemical parameters of blood}

The results obtained of biochemical parameters assessments of fish blood at termination of the experiment are presented in Table5. There were no significant differences $(\mathrm{P}<0.01)$ in mean values of creatinine triglyceride, lipase, glucose, albumin and globulin among all the diets, while cholesterol and amylase varied significantly. For the juveniles maintained at $\mathrm{T}_{0}$ and $\mathrm{T}_{25}$ were significantly higher in cholesterol than the other juveniles. But juveniles maintained at $T_{75}$ were having significantly $(\mathrm{P}<0.01)$ higher amylase than the other group. Study the blood file in fish is one of the most important indicators of the physiological state of fish. Some studies showed that the most important fish fatigue due to exposure to toxins leads to high blood glucose levels as a result of glycolysis. ${ }^{23}$ As the low content of albumin and globulin in the blood leads to proteinaemia, as it is a sign of impaired liver function. ${ }^{24}$ or lack of protein synthesis in the liver ${ }^{25}$ and accumulative creatinine may be due to kidney disease and muscle 
breakdown. ${ }^{26}$ cholesterol is involved in building the cell structure and is therefore an important blood component, as metabolic disturbances of both fats and lipoproteins lead to high levels of cholesterol in the serum as well as an indication of liver disease. ${ }^{27}$ Also, other studies have shown the main enzymes responsible for digestion in fish are amylase, protease and lipase. These enzymes control the fish's efficiency in digesting food and its protein, carbohydrate and fat components mentioned by Lemieux et al. ${ }^{28}$
In the present study, the results showed that the use of different levels of EWM did not lead to significant differences in lipase, while there was a significant increase in amylase in fish that were fed by $T_{50}$ and $T_{75}$ than the other. Also, the blood analysis of Nile tilapia did not show significant differences in cholesterol, triglyceride, lipase, glucose, albumin and globulin according to the different in experimental diets and a decrease in the serum content of cholesterol by increasing the content of EWM. Therefore, it is possible to predict that EWM works to facilitate digestion and improve liver function.

Table 5 Mean values \pm Se of Biochemical blood parameters of Nile tilapia (O. niloticus) at the end of the experimental diet

\begin{tabular}{|c|c|c|c|c|c|}
\hline Parameters & C & $\mathbf{T}_{25}$ & $T_{50}$ & $T_{75}$ & $T_{100}$ \\
\hline Creatinine & $0.43 \pm 0.02^{\mathrm{a}}$ & $0.43 \pm 0.0 \mathrm{I}^{\mathrm{a}}$ & $0.42 \pm 0.02^{\mathrm{a}}$ & $0.44 \pm 0.02^{\mathrm{a}}$ & $0.43 \pm 0.0 \mathrm{I}^{\mathrm{a}}$ \\
\hline Cholesterol & $113 \pm 2.08^{a}$ & $112 \pm 2.52^{\mathrm{a}}$ & $105 \pm 3.79^{b}$ & $103 \pm 1.15^{\mathrm{b}}$ & $101 \pm 1.15^{b}$ \\
\hline Triglyceride & $\mathrm{I} 15.66 \pm 2.08^{\mathrm{a}}$ & $1|4.7| \pm 3.06^{\mathrm{a}}$ & || $4.86 \pm 2.08^{a}$ & $\mid 14.72 \pm 1.53^{\mathrm{a}}$ & $|I 4.0| \pm I .53^{\mathrm{a}}$ \\
\hline Amylase & $208.6 \pm 3.46^{b}$ & $208.3 \pm 5.13^{a}$ & $208 \pm 3.2 \mathrm{I}^{\mathrm{b}}$ & $209.42 \pm 2.89^{a}$ & $208.82 \pm 2.89^{b}$ \\
\hline Lipase & $3.02 \pm 0.12^{\mathrm{a}}$ & $3.10 \pm 0.15^{\mathrm{a}}$ & $3.02 \pm 0.06^{\mathrm{a}}$ & $3.01 \pm 0.10^{\mathrm{a}}$ & $310 \pm 0.10^{a}$ \\
\hline Glucose & $103.1 \mid \pm 3.2 I^{\mathrm{a}}$ & $104.21 \pm 2.08^{a}$ & $103.30 \pm 1.73^{a}$ & $|03.3| \pm 0.58^{a}$ & $103.01 \pm 0.58^{\mathrm{a}}$ \\
\hline Albumin & $4.3 I \pm 3.2 I^{a}$ & $4.22 \pm 3.2 \mathrm{I}^{\mathrm{a}}$ & $4.52 \pm 3.2 \mathrm{I}^{\mathrm{a}}$ & $4.55 \pm 3.2 \mathrm{I}^{\mathrm{a}}$ & $4.7 I \pm 3.2 I^{\mathrm{a}}$ \\
\hline Globulin & $\mathrm{I} .63 \pm 3.2 \mathrm{I}^{\mathrm{a}}$ & $1.33 \pm 3.2 \mathrm{I}^{\mathrm{a}}$ & $\mathrm{I} .59 \pm 3.2 \mathrm{I}^{\mathrm{a}}$ & $1.7 I \pm 3.2 I^{\mathrm{a}}$ & $\mathrm{I} .40 \pm 3.2 \mathrm{I}^{\mathrm{a}}$ \\
\hline
\end{tabular}

\section{Biochemical composition of the experimental diets}

The results obtained of means of biochemical composition of Nile tilapia juveniles are shown in Table 6. Crude protein content increased significantly $(\mathrm{P}<0.01)$ when fed at $\mathrm{T}_{0}, \mathrm{~T}_{75}, \mathrm{~T}_{100}$. Differences in body moisture content at different replacement levels were not significant. While average lipid content less significantly $(\mathrm{P}<0.01)$ when fed the $\mathrm{T}_{0}$ diet.
It was noted at the end of this study that Biochemical composition of Nile tilapia body showed significant differences according to the differences in experimental diets. Fish maintained at $\mathrm{T}_{50}$ and $\mathrm{T}_{75}$ showed a significant increase in the total body protein than the other fish (Table 6). Body EE for fish using EWM exceeded than control diet, while there were no significant differences in the total body content of moisture.

Table 6 Mean values \pm SE of Biochemical composition of Nile tilapia (O. niloticus) at the end of the feeding trial (dry matter weight basis).

\begin{tabular}{llllll}
\hline Parameters & $\mathbf{T}_{0}$ & $\mathbf{T}_{25}$ & $\mathbf{T}_{50}$ & $\mathbf{T}_{75}$ & $\mathbf{T}_{100}$ \\
Moisture & $76.29 \pm 0.64^{\mathrm{a}}$ & $76.19 \pm 0.52^{\mathrm{a}}$ & $76.08 \pm 1.09^{\mathrm{a}}$ & $76.22 \pm 0.66^{\mathrm{a}}$ & $76.05 \pm 0.36^{\mathrm{a}}$ \\
CP & $65.68 \pm 0.18^{\mathrm{a}}$ & $64.76 \pm 0.37^{\mathrm{b}}$ & $64.52 \pm 0.32^{\mathrm{b}}$ & $66.63 \pm 0.05^{\mathrm{a}}$ & $65.35 \pm 0.11^{\mathrm{a}}$ \\
EE & $17.74 \pm 0.08^{\mathrm{b}}$ & $20.10 \pm 0.45^{\mathrm{a}}$ & $21.41 \pm 0.26^{\mathrm{a}}$ & $19.49 \pm 0.34^{\mathrm{ab}}$ & $19.34 \pm 0.18^{\mathrm{ab}}$ \\
& $16.54 \pm 0.36^{\mathrm{a}}$ & $15.13 \pm 0.35^{\mathrm{ab}}$ & $14.03 \pm 0.58^{\mathrm{b}}$ & $13.86 \pm 0.33^{\mathrm{b}}$ & $15.26 \pm 0.55^{\mathrm{a}}$ \\
\hline
\end{tabular}




\section{Conclusion}

From the results of this study, the assimilation of earth warm in the diet of Oreochromis niloticus has supported good growth performance. Based on the results obtained from the study, it can be concluded that $75 \%$ replacement of fishmeal with earthworm meal in the diet may be used as an ideal alternative protein source for better growth performance of this fish species.

\section{Conflits of interest}

The author declares that there is no conflicts of interest.

\section{Acknowledgments}

The author would like to give cordial thanks to Aswan governorate for their constant support to carry out the research.

\section{Funding}

None.

\section{References}

1. FAO. World Review of Fisheries and Aquaculture. FAO, Rome. 2012. $241 \mathrm{p}$.

2. Singh R, Srivastava P, Singh P, et al. Human Overpopulation and Food Security: Challenges for the Agriculture Sustainability. In KhosrowPour, editor. Urban Agriculture and Food Systems: Breakthroughs in Research and Practice. Pennsylvania, United States: IGI Global. 2019. p. 439-467.

3. Goddard S, Al-Shagaa G, Ali A. Fisheries by-catch and processing waste meals as ingredients in diets for Nile tilapia, Oreochromis niloticus. Aquaculture Research. 2008;39(5):518-525.

4. Sogbesan AO, Ugwumba AA. Nutritional Values of Some NonConventional Animal Protein Feedstuffs Used as Fishmeal Supplement in Aquaculture Practices in Nigeria. Turkish Journal of Fisheries and Aquatic Sciences. 2008;8(1):159-164.

5. Ng WK, Liew FL, Ang LP, et al. Potential of mealworm (Tenebrio molitor) as an alternative protein source in practical diets for African catfish, Clarias gariepinus. Aquacult Research. 2001;32(1):273-280.

6. Pucher J, Mayrhofer R, El-Matbouli M, et al. Effects of modified pond management on limnological parameters in small scale aquaculture ponds in mountainous Northern Vietnam. Aquacult Research. 2016;47(1):56-70.

7. Monebi CO, Ugwumba AAA. Utilization of the earthworm, Eudrilus eugeniae in the diet of Heteroclarias fingerlings. International Journal of Fisheries and Aquaculture. 2012;5(2):19-25.

8. Sharma K, Garg VK. Comparative Analysis of Vermicompost Quality Produced from Rice Straw and Paper Waste Employing Earthworm Eisenia fetida (Sav.). Bioresource Technology. 2018;250:708-715.

9. Maková J, Javoreková S, Elbl J, et al. Impact of Vermicompost on Biological Indicators of the Quality of Soil under Maize in a Greenhouse Experiment. Journal of Elementology. 2019;24(1):319330 .

10. Ncobela CN, Chimonyo M. Potential of Using Non-Conventional Animal Protein Sources for Sustainable Intensification of Scavenging Village Chickens: A Review. Animal Feed Science and Technology. 2015;208:1-11.

11. Tiroesele B, Moreki JC. Termites and Earthworms as Potential Alternative Sources of Protein for Poultry. International Journal for
Agro Veterinary and Medical Sciences. 2012;6(5):368-376.

12. Gunya B, Masika PJ, Hugo A, et al. Nutrient Composition and Fatty Acid Profiles of Oven-Dried and Freeze-Dried Earthworm Eiseniafetida. Journal of Food and Nutrition Research. 2016;4(6):343-348.

13. APHA. Standard methods for examination of water and waste water. American Public Health Association, Washington, DC. 1995.

14. Sherman S, Pradhan K, Satya S, et al. Potentiality of earthworms for waste management and in other uses -The Journal of American Science. 2003;1:4-16.

15. Congleton JL, La Voie WJ. Comparison of blood chemistry values for samples collected from juvenile Chinook salmon by three methods. Journal of Aquatic Animal Health. 2001;13(2):168-172.

16. Henry RJ. Colorimetric determination of total protein. In: Clinical Chemistry. Harper and Row Publisher. New York. 1964; p 181.

17. Chawla R. Practical clinical biochemistry (methods and interpretations). 3th ed. Jaypee Brothers. New Delhi, India. 2003.

18. Istiqomah L, Sofyan A, Damayanti E. Amino acid profile of earthworm and earthworm meal (Lumbricus rubellus) for animal feedstuff. Journal of the Indonesian Tropical Animal Agriculture. 2009;34(4):253-257.

19. Serna Cock L, Rengifo Guerrero CA, Rojas Restrepo MA. Use of earthworm (Eisenia fetida) flour and hydrolyzed chicken feathers as sources of nitrogen and minerals for ethanol production. Waste \& Biomass Valorization. 2017;1:1-10.

20. Omeru ED, Solomon RJ. Comparative analysis on the growth performance of catfish (Clarias Gariepinus) fed with earthwork as a replacement of fish meal. American Journal of Research Communication, 2016;4(6):89-125.

21. Bisht SP, Kaushal BR. Estimation of earthworm protein for poultrty industry. Him. Journal of Environment and Zoology. 2001;15:117122 .

22. Chakrabarty D, Das SK, Das MK, et al. Application of vermitechnology in aquaculture. Dynamic Soil Dynamic Plant. 2009;7(2):41-44

23. Hog H. Effects of sublethal concentration of Zinc II sulphate heptahydrate ( $\mathrm{Zn} \mathrm{SO} 4.7 \mathrm{H} 2 \mathrm{O}$ ) on blood glucose level of fresh water fish Heteropneustes fossilis. International Journal of Scientific Technology Research. 2014;3(5):128-131.

24. Mahdi B. Physiological dysfunction in fish after insecticides exposure. 2013.

25. Joseph B, Raj SJ. Effect of Curacron toxicity on the total serum protein content of Cyprinus carpio. Toxicological and Environmental Chemistry. 2010;92(10):1889-1893.

26. Jana B, Helena M, Marie S, et al. Evaluation of Biochemical, Haematological, and Histopathological Responses and Recovery Ability of Common Carp (Cyprinus carpio L.) after Acute Exposure to Atrazine Herbicide. Hindawi Publishing Corporation. Bio Med Research International Article. 2014.

27. Kavadias S, Castritsi-Catharios J, Dessypris jappiichthyoi. Annual cycles of growth rate, feeding rate, food conversion, plasma glucose and plasma lipids in a population of European sea bass (Dicentrarchus labrax L.) farmed in floating marine cages. 2004;19(1):29-34.

28. Lemieux H, Blier P, Dutil JD. Do digestive enzymes set a physiological limit on growth rate and food conversion efficiency in the Atlantic cod (Gadus morhua)? Fish Physiology and Biochemistry. 1999;20:293303. 